UDC $550.3(519.21)$

Z. Vyzhva, Dr. Sci. (Phys.-Math.), Assoc. Prof. E-mail: zoya_vyzhva@ukr.net,

A. Vyzhva, Msc

E-mail: motomustanger@ukr.net, Institute of Geology

Taras Shevchenko National University of Kyiv 90 Vasylkivska Str., Kyiv, 03022 Ukraine

\title{
METHODS OF STATISTICAL SIMULATION OF RANDOM FIELDS ON THE PLANE BY THE AIRCRAFT MAGNETOMETRY DATA
}

\author{
(Рекомендовано членом редакційної колеаії д-ром фріз.мат. наук, проф. Б. П. Масловим)
}

Universal methods of statistical simulation (Monte Carlo methods) of geophysical data for generating random processes and fields on 2-D grids of required detail and regularity have been developed. Most of the geophysical research results are submitted in digital form, which accuracy depends on various random effects (including equipment measurement error). The map accuracy problem occurs when the data cannot be obtained with a given detail in some areas. Methods of statistical simulation of realizations of random processes and multi-dimensional random functions (random fields), to solve the problems of conditional maps, adding of data to achieve the necessary precision, and other such problems in geophysics are proposed to be applied. Theorems on the mean-square and another approximation of homogeneous and isotropic random 2-D fields by special partial sums have been proved. A randomization method was used to formulate algorithms of statistical simulation by means of these theorems. A new effective statistical technique has been devised to simulate random fields in 2-D space (randomization method, spectral coefficients method and others) for geophysical problems. random fields in 2-D space statistical simulation based on spectral representation has been introduced in order to enhance map accuracy by the example of aeromagnetic survey data in the Ovruch depression. It is divided into deterministic and random components for data analysis. The deterministic component is proposed to approximate by cubic splines and the stationary random component is proposed to model on the basis of spectral expansions of random fields. Model example is the aircraft magnetometry data 2-D field (on the plane). According to the algorithm we received noise implementations on the study area with double detalization for each profile. When checking their adequacy we came to the conclusions that the relevant random components histogram has Gaussian distribution. The built variogram of these implementations has the best approximation by theoretical variogram which is connected to the Bessel type correlation function. The final stage was the imposing array of noise on the spline approximation of real data. As a result, we received more detailed implementation for the geomagnetic observation data in the selected area.

Keywords: Statistical simulation, randomizations method, spline-interpolation, conditional maps.

Introduction. The problems of the simulation of 2-D random fields with given probability characteristics arise solving the actual geophysics problems. In this case a special care is necessary for reduction of calculations, amount of which rapidly grow together with the dimension of the argument of the random field. Different approaches related to the solving of problems of statistical simulation of random fields where described in a lot of papers.

In this paper the algorithms of statistical simulation of Gaussian homogeneous and isotropic random fields on the plane using the basic spectral representation [3] are considered.

There has been an introduced random field in 2-D space statistical simulation based on spectral representation in order to enhance map accuracy by the example of aeromagnetic survey data in the Ovruch depression.

The spectral representation of homogeneous and isotropic random fields and approximation theorems.
Let $\xi(x), x \in R_{2}$, is real-valued square-mean continuous homogeneous and isotropic random fields on the plane. It means, that $E \xi(x)=$ const (later on we assume that $E \xi(x)=0$, and $E \xi(x) \xi(y)=B(|x-y|)$, where $\rho=|x-y|$ is the distance between the point $x$ and $y$. It is known [3] that

$$
B(\rho)=\int_{0}^{\infty} J_{0}(\lambda \rho) d \Phi(\lambda)
$$

where $\Phi(\lambda)$ is the bounded nondecreasing function and $J_{m}(x)$ is the Bessel function of the first kind with the index 0 . Let $(r, \varphi)$ are polar coordinates of a point $x$.

The random field $\xi(x)$ admits [3] the spectral representation

$$
\xi(r, \varphi)=\sum_{k=0}^{\infty} \sqrt{v_{k}}\left[\operatorname{cosk} \varphi \int_{0}^{\infty} J_{k}(\lambda r) Z_{k}^{1}(d \lambda)+\operatorname{sink} \varphi \int_{0}^{\infty} J_{k}(\lambda r) Z_{k}^{2}(d \lambda)\right],
$$

where $\left\{Z_{k}^{i}(\cdot)\right\}_{k=0}^{\infty}, \quad(i=1,2)$ are sequences of real valued orthogonal random measures on Borel subsets from the snterval $[0,+\infty)$, i. e.

$$
E Z_{k}^{i}\left(S_{1}\right) Z_{n}^{j}\left(S_{2}\right)=\delta_{i}^{j} \delta_{k}^{n} \Phi\left(S_{1} \cap S_{2}\right),(i, j=1,2),
$$

for any Borel subsets $S_{1}$ and $S_{2}$, and

$$
v_{k}= \begin{cases}1, & k=0 \\ 2, & k>0\end{cases}
$$

If $\xi(x)$ is a Gaussian random field, then the random measures $\left\{Z_{k}^{i}(\cdot)\right\}_{k=0}^{\infty},(i=1,2)$ is Gaussian random measures with independent values.

$$
\xi_{m}^{N}(r, \varphi)=\sum_{i=1}^{m} \sum_{k=0}^{N} \sqrt{v_{k}}\left[\operatorname{cosk} \varphi \int_{\Lambda_{i}} J_{k}(\lambda r) Z_{k}^{1}(d \lambda)+\operatorname{sink} \varphi \int_{\Lambda_{i}} J_{k}(\lambda r) Z_{k}^{2}(d \lambda)\right], \quad n \in N .
$$


Let us assume in what follows that

$$
\operatorname{Var} \xi(x)=\int_{0}^{\infty} d \Phi(\lambda)=1
$$

Then

$$
\sum_{i=1}^{m-1} \int_{\Lambda_{i}} d \Phi(\lambda)=\int_{0}^{d_{m}} d \Phi(\lambda) \leq 1
$$

and the following statement is valid.

THEOREM 1. Let $m, N$, and am tend to infinity in such a way that the following conditions hold:
1) $\frac{N}{\sqrt{a_{m}}} \rightarrow \infty$;
2) $\frac{a_{m}}{N} \rightarrow 0$;
3) $\frac{N}{m}=0(1)$;
4) $\frac{a_{m}{ }^{2}}{m} \rightarrow 0$;
5) $N \int_{a_{m}}^{\infty} d \Phi(\lambda) \rightarrow 0$;
6) $\max _{1 \leq i \leq m-1} d_{i} \leq \frac{c a_{m}}{m} \quad(c \in R)$.

Then

$$
E \int_{|x| \leq Q}\left[\xi(\bar{x})-\xi_{m}^{N}(\bar{x})\right]^{2} d \bar{x} \rightarrow 0, \quad m \rightarrow \infty
$$

and the following estimate

$$
\begin{aligned}
& E \int_{|x| \leq Q}\left[\xi(\bar{x})-\xi_{m}^{N}(\bar{x})\right]^{2} d \bar{x} \leq \frac{2}{\pi} Q^{4}\left(\frac{c a_{m}}{m}\right)^{2}(2 N+1)+ \\
& +2 \pi Q^{2}(4 N+3) \int_{a_{m}}^{\infty} d \Phi(\lambda)+2 \sqrt{Q \pi} \frac{Q^{2}}{N+3} \frac{\sqrt{a_{m}}}{N} e^{-\frac{N^{2}}{a_{m} Q}}
\end{aligned}
$$

is valid.

And the following estimate is true

$$
\begin{gathered}
E\left\|\xi(x)-\xi_{m}^{N}(x)\right\|^{2} w_{2}^{1}\left(V_{Q}\right) \leq 2 Q^{2}\left(\frac{Q^{2}}{\pi}+2 \frac{\mu_{2}}{\pi}+\pi\right)(2 N+1)\left(c \frac{a_{m}}{m}\right)^{2}+ \\
+2 \pi Q^{2}\left[(4 N+3) \int_{\Lambda_{m}} d \Phi(\lambda)+(2 N+1) \int_{\Lambda_{m}}\left(\lambda^{2}+\lambda^{2}\right) d \Phi(\lambda)+\frac{5}{4} \int_{\Lambda_{m}} \lambda^{2} d \Phi(\lambda)\right]+ \\
+\left[2 \frac{Q}{N(N+1)} \sqrt{\pi Q a_{m}}+\pi \mu_{2}\left(\frac{Q}{a_{m}}+\frac{a_{m} Q}{2(N+2)(N+4)}\right) \frac{1}{2 N} \sqrt{\frac{Q a_{m}}{\pi}}+\right. \\
\left.+2 Q a_{m} \sqrt{\frac{\pi Q a_{m}}{N}}\right] e^{-\frac{N^{2}}{a_{m} Q}}+\frac{8 Q^{2}}{\pi} S_{N}\left[\left(\frac{c a_{m}}{m}\right)^{2}+2 \int_{\Lambda_{m}}\left(\lambda^{2}+\lambda_{m}^{2}\right) d \Phi(\lambda)\right] .
\end{gathered}
$$

where $S_{N}=\sum_{k=1}^{N} k^{2}$.

The proof is provided in the same way as that of Theorem 1 .

THEOREM 3. Let (10) hold and

$\xi_{m}^{N}(r, \varphi)=$

$$
=\sum_{k=0}^{N} \sqrt{v_{k}}\left[\operatorname{cosk} \varphi \int_{0}^{\infty} J_{k}(\lambda r) Z_{k}^{1}(d \lambda)+\operatorname{sink} \varphi \int_{0}^{\infty} J_{k}(\lambda r) Z_{k}^{2}(d \lambda)\right] \text {, }
$$

then

$$
E\left[\xi(\bar{x})-\xi_{m}^{N}(\bar{x})\right]^{2} \leq \frac{1}{\pi N}\left(\frac{1}{2} r \mu_{1}+r^{2} \mu_{2}\right)
$$

where

$$
\mu_{k}=\int_{0}^{\infty} \lambda^{k} d \Phi(\lambda)
$$

Theorem 3 is proved in [2].

Let

$\xi_{N}^{a}(r, \varphi)=$

$=\sum_{k=0}^{N} \sqrt{v_{k}}\left[\operatorname{cosk} \varphi \int_{0}^{a} J_{k}(\lambda r) Z_{k}^{1}(d \lambda)+\operatorname{sink} \varphi \int_{0}^{a} J_{k}(\lambda r) Z_{k}^{2}(d \lambda)\right]$,
Assume that $\quad \mu_{2}=\int_{0}^{\infty} d \Phi(\lambda)<+\infty$.

This condition provides the existence of derivatives $\frac{\partial \xi}{\partial r}, \frac{\partial \xi}{\partial \varphi}$. Let $V_{Q} \leq\{x:|x| \leq Q\}$ and let

$$
\begin{gathered}
\left\|\xi(x)-\xi_{m}^{N}(x)\right\|^{2} w_{2}^{1}\left(V_{Q}\right)=\int_{V_{Q}}\left|\xi(x)-\xi_{m}^{N}(x)\right|^{2} d x+ \\
+\int_{V_{Q}}\left|\frac{\partial \xi}{\partial r}-\frac{\partial \xi}{\partial \varphi}\right|^{2} d x+\int_{V_{Q}} \frac{1}{r^{2}}\left|\frac{\partial \xi}{\partial r}-\frac{\partial \xi}{\partial \varphi}\right|^{2} d x
\end{gathered}
$$

is Sobolev's norm of $\xi(x)-\xi_{m}^{N}(x)$ in the Sobolev's space ment can be formulated.

THEOREM 2. Let us assume that:

1) $\mu_{2}=\int_{0}^{\infty} d \Phi(\lambda)<+\infty$,

2) the condition of Theorem 1 holds,

3) $N^{3}\left(\frac{a_{m}}{m}\right)^{2} \rightarrow 0$, if $m \rightarrow \infty$

4) $N^{3} \int_{\Lambda_{m}}\left(\lambda^{2}+\lambda_{m}^{2}\right) d \Phi(\lambda) \rightarrow 0$, if $m \rightarrow \infty$.

$$
E\left\|\xi(x)-\xi_{m}^{N}(x)\right\|^{2} w_{2}^{1}\left(V_{Q}\right) \rightarrow 0, \text { if } m \rightarrow \infty .
$$

Theorem 1 is proved in [2]. $w_{2}^{1}\left(V_{Q}\right)$ on the circle with radius $Q$. Now the next state-
We consider the partition

And choose the point $\lambda_{i}$ in every interval $\left(u_{i-1}, u_{i}\right]$. Let

$$
\begin{gathered}
\xi_{N}^{a, \pi_{m}}(r, \varphi)==\sum_{k=0}^{N} \sqrt{v_{k}}\left[\operatorname{cosk} \varphi \sum_{i=1}^{m} J_{k}(\lambda r) Z_{k}^{1}\left(u_{i-1}, u_{i}\right]\right)+ \\
\left.+\operatorname{sink} \varphi \sum_{i=1}^{m} J_{k}(\lambda r) Z_{k}^{2}\left(\left(u_{i-1}, u_{i}\right]\right)\right]
\end{gathered}
$$

THEOREM 4. The following inequalities hold:

$$
\begin{gathered}
E\left[\xi_{N}^{a}(r, \varphi)-\xi_{N}^{a, \pi_{m}}(r, \varphi)\right]^{2} \leq \int_{a}^{\infty} d \Phi(\lambda), \\
E\left[\xi_{N}^{a}(r, \varphi)-\xi_{N}^{a, \pi_{m}}(r, \varphi)\right]^{2} \leq \\
\leq\left(\frac{2 r}{\pi}\right)^{2}(2 N+1) \max _{1 \leq i \leq m} d_{i}^{2}[\Phi(a)-\Phi(0)], \\
E\left[\xi_{N}^{a}(r, \varphi)-\xi_{N}^{a, \pi_{m}}(r, \varphi)\right]^{2} \leq 3\left\{\frac{1}{\pi N}\left(\frac{1}{2} r \mu_{1}+r^{2} \mu_{2}\right)+\right.
\end{gathered}
$$

$$
\pi_{m}(0, a)=\left\{u_{0}=0<u_{1}<u_{2}<\ldots<u_{m-1}<u_{m}=a\right\},
$$
a $>0$. 


$$
\left.+\int_{0}^{\infty} d \Phi(\lambda)+\left(\frac{2 r}{\pi}\right)^{2}(2 N+1) \max _{1 \leq i \leq m} d_{i}^{2}[\Phi(a)-\Phi(0)]\right\},
$$

where $d_{i}=\left|u_{i}-u_{i-1}\right|$.

The algorithms of the statistical simulation of the Gaussian homogeneous and isotropic random fields

Using the approximation theorems the algorithm of the statistical simulation of realizations of homogeneous and isotropic random fields may be formulated. We formulate two algorithms of such kind. The first one, based on the idea of randomization proposed by G.A. Mikhailov in [6-7] is called randomization algorithm. Assume that the spectral density $\tau(u)=\Phi^{\prime}(u)$ exists.

Algorithm 1.

Choose $\mathrm{N}$ and am using approximating theorems;

Take the partition (4) and calculate $p_{i}=\int_{\Lambda_{i}} \mathrm{~d} \Phi(\lambda)$.

In each domain $\Lambda_{i}(i=\overline{1, m})$ take a random point $\lambda_{i}, \lambda_{i} \in \Lambda_{i}(i=\overline{1, m})$ with the distribution density

$$
p_{i}(u)= \begin{cases}\frac{\tau(u)}{p_{i}}, & u \in \Lambda_{i}, \\ 0, & u \notin \Lambda_{i},\end{cases}
$$

Simulate the sequences of independent standart Gaussian random variables

$$
\left\{Z_{k}^{i, j}: j=1,2 ; k=\overline{0, N} ; i=\overline{1, m}\right\}
$$

Calculate the realization of the stochastic random field

$$
\begin{aligned}
\xi_{N}^{m}(r, \varphi)= & =\sum_{i=1}^{m} \sqrt{p_{i}} \sum_{k=0}^{N} \sqrt{v_{k}}\left[\operatorname{cosk} \varphi J_{k}\left(\lambda_{i} r\right) Z_{k}^{i, 1}+\right. \\
& \left.+\operatorname{sink} \varphi J_{k}\left(\lambda_{i} r\right) Z_{k}^{i, 2}\right],
\end{aligned}
$$

Check whether the realization of therandom field generated in step 5 fits the data by testing the corresponding statistical characteristics.

Now we describe the algorithm based on Theorem 4.

Algorithm 2.

Choose the number $\mathrm{N}$ such that

$$
\frac{1}{\pi N}\left(\frac{1}{2} r \mu_{1}+r^{2} \mu_{2}\right)<\frac{\varepsilon}{3}
$$

Choose a such that

$$
\int_{a}^{\infty} d \Phi(\lambda)<\frac{\varepsilon}{3}
$$

Define the partition $\pi_{m}(0, a)$ of the interval $(0, a]$, such that

$$
\left(\frac{2 r}{\pi}\right)^{2}(2 N+1) \max _{1 \leq i \leq m} d_{i}^{2}[\Phi(a)-\Phi(0)] \rightarrow 0 ; m \rightarrow \infty
$$

Choose the point $\lambda_{i}$ in every interval $\left(u_{i-1}, u_{i}\right]$.

Simulate the sequences of independent Gaussian random variables

$$
\left\{\zeta_{k}^{i, j}: j=1,2 ; k=\overline{0, N} ; i=\overline{1, m}\right\}
$$

with zero expectation and the variance

$$
\operatorname{Var}_{\zeta_{k}^{i, j}}^{i}=\Phi\left(u_{i}\right)-\Phi\left(u_{i-1}\right)
$$

Calculate the realization of the stochastic random field

$$
\begin{aligned}
\xi_{N}^{a, \pi_{m}}(r, \varphi) & ==\sum_{k=0}^{N}{\sqrt{v_{k}}}_{i=1}^{m}\left[\operatorname{cosk} \varphi J_{k}\left(\lambda_{i} r\right) \zeta_{k}^{i, 1}+\right. \\
& \left.+\operatorname{sink} \varphi J_{k}\left(\lambda_{i} r\right) \zeta_{k}^{i, 2}\right]
\end{aligned}
$$

Check whether the realization of therandom field generated in step 6 fits the data by testing the corresponding statistical characteristics

The randomizing variant of this algorithm may be suggested in the case when the distributions of the random points $\left\{\lambda_{i}\right\}$ are described by (19).

In this case it is necessary to calculate

$$
\begin{aligned}
\xi_{N}^{a, \pi_{m}}(r, \varphi) & ==\sum_{i=1}^{m} \sqrt{p_{i}} \sum_{k=0}^{N} \sqrt{v_{k}}\left[\operatorname{cosk} \varphi J_{k}\left(\lambda_{i} r\right) Z_{k}^{i, 1}+\right. \\
& \left.+\operatorname{sink} \varphi J_{k}\left(\lambda_{i} r\right) Z_{k}^{i, 2}\right],
\end{aligned}
$$

3. Statistical simulation methods of random fields on the plane by the aircraft magnetometry data

Most of the geophysical research results are submitted in digital form, which accuracy depends on various random effects (including equipment measurement error). The map accuracy problem occurs when the data cannot be obtained with a given detail in some areas. In such cases the methods of statistical modelling realizations of random processes and random multivariate functions (random fields) are recommended [1-2, 4-8] to supplement data missing. These methods have been developed for more than 20 years at the Mechanics and Mathematics Faculty at Taras Shevchenko National University of Kyiv. They were offered by professor and corresponding member of NAS of Ukraine M.Y. Yadrenko as a separate area for research and as a means to applied aspects.

While constructing data graphs for each account, we noticed that it is expedient to distinguish deterministic and random components. Deterministic function can be selected in different ways. One determination method its analytical form (trend $f_{i}(x)$ as a function of exponentially damped sinusoid or cosinusoid) was considered in [8]. But there is a more accurate way to select deterministic component - approximation by cubic spline data. The difference between spline approximation of data with gaps (e.g. due to one) for each profile and spline curve for all points is a random process that is also stationary for most profiles.

According to graphs for each profile the stationary random component $\xi_{i}(x)$ ("noise" - random process) and trend $f_{i}(x)$ as determined spline function were selected. Input data on the profile is a random process $\eta_{i}(x)$ :

$$
\eta_{i}(x)=f_{i}(x)+\xi_{i}(x), \quad i=7,8, \ldots, 20
$$

Solid line on Fig. 1 shows a deposited spline approximation $S_{i}^{(1)}(x)$, built by means of the MathCad software for PR1 data that are taken without spaces. Parameters defined by the data were determined for such spline. They ask each profile trend $f_{i}(x)$. Dashed line shows the spline approximation graph $S_{i}^{(2)}(x)$ of the first profile data with gaps due to one point of observation (i.e. for 50 points out of 100). Noise was obtained by calculating the following difference:

$$
\xi_{i}(x)=S_{i}^{(1)}(x)-S_{i}^{(2)}(x), \quad i=7,8, \ldots, 20
$$




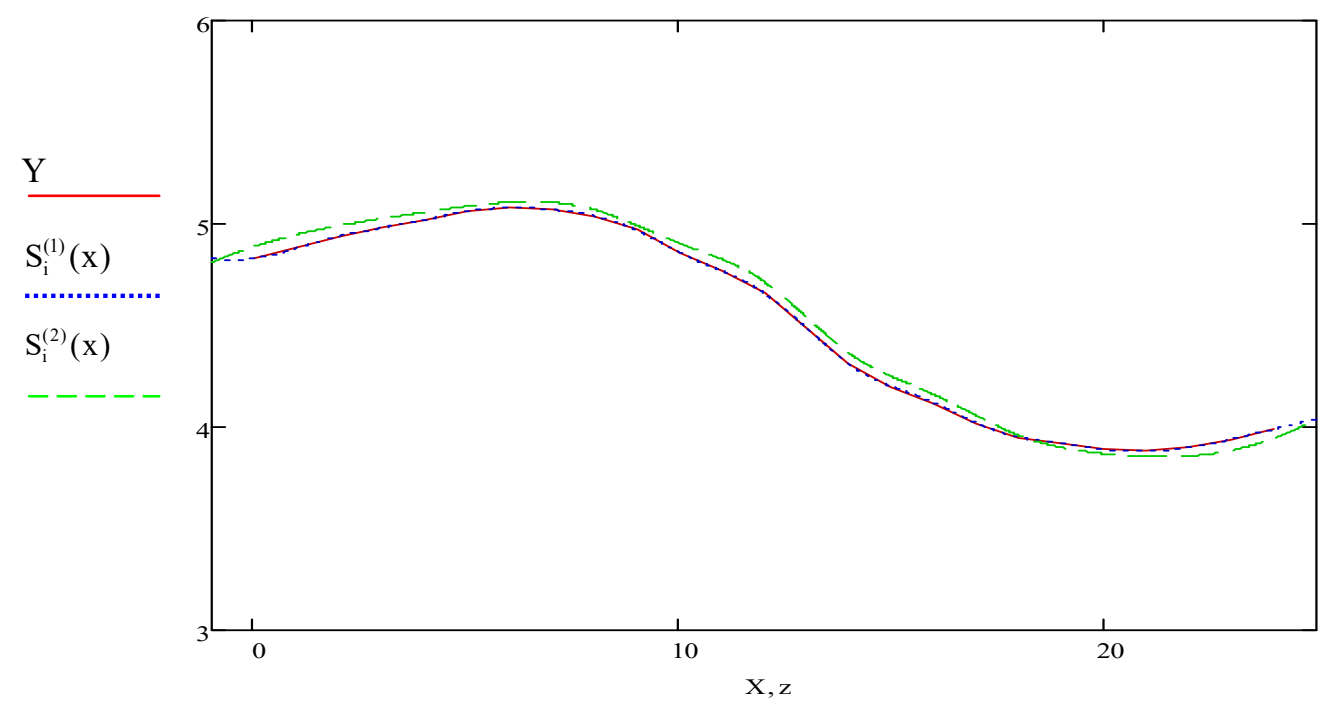

Fig. 1. Logarithmic input data and spline $\Delta T$ Tan in PR1

From observations (values) of noise $\xi_{i}(x)$ in all 13 profiles we created two-dimensional array that represents homogeneous and isotropic random field $\xi_{i}(r, \varphi)$ on the plane ( $r$ and $\varphi$ - polar coordinates of $x$ point) with zero mathematical expectation. By fields of such properties we can apply the method of statistical modelling of random fields based on their spectral expansions [4], which allows finding the perfect image of entire observations field for their certain implementation values. So we generate additional noise data in the points where geomagnetic measurements were not carried out, for example, with double precision intervals of 50 compare to 100 meters. We can impose this data on the spline curve trend $S_{i}^{(1)}(x)$ for each profile and obtain more detailed aeromagnetic survey data. This method differs from the traditional, which uses average value of neighboring measured points for calculation point. Our method takes into account the correlation between data points and their statistical distribution. The idea of its use to resolve the problem described in paper belongs to Vyzhva A.S. Using the above method makes it possible to supplement the missing data in the study area, taking into account their statistical nature.

According to the algorithm 2 we received noise implementations on the study area with double precision (200 points) for each profile (13 profiles). When checking their adequacy we made the conclusions that the relevant noise histogram (Fig. 2) has Gaussian distribution. The built variogram of these implementations has the best approximation by theoretical variogram which is connected to the Bessel type correlation function for parameter $a \approx 3,25$ * 105 :

$$
B(\rho)=\frac{2 J_{1}(a \rho)}{a \rho}, \quad(a>0)
$$

This confirms the adequacy of simulated implementations to the real research data.

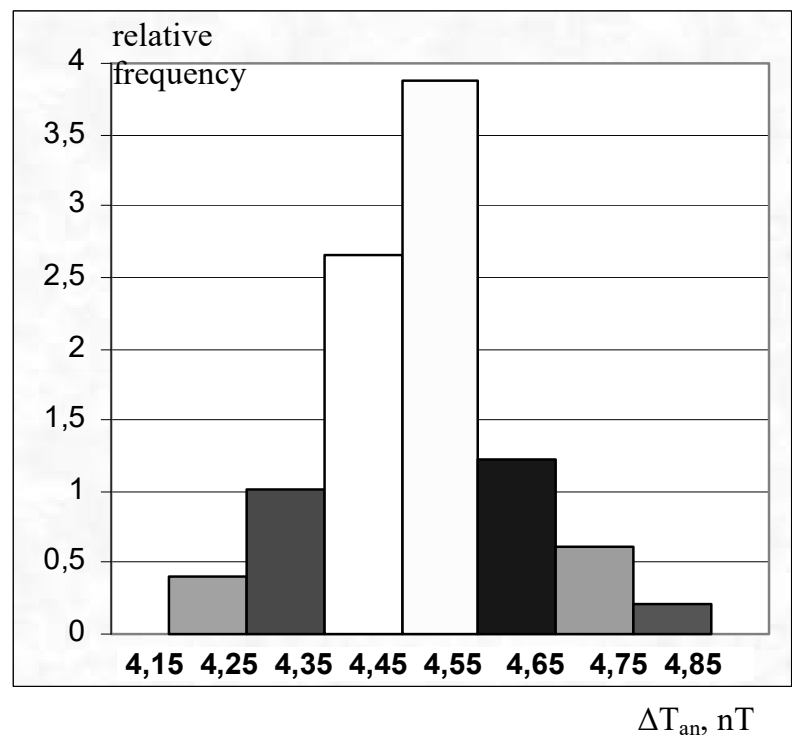

Fig. 2. Histogram of logarithmic $\Delta$ Tan simulated data in PR1

Variogram of simulated and input data arrays $\Delta T$ Tan for PR7-PR20, corresponding to Bessel type correlation func- tion (24) at the value of the parameter $a \approx 3,25 * 105$ is shown on Fig. 3. 


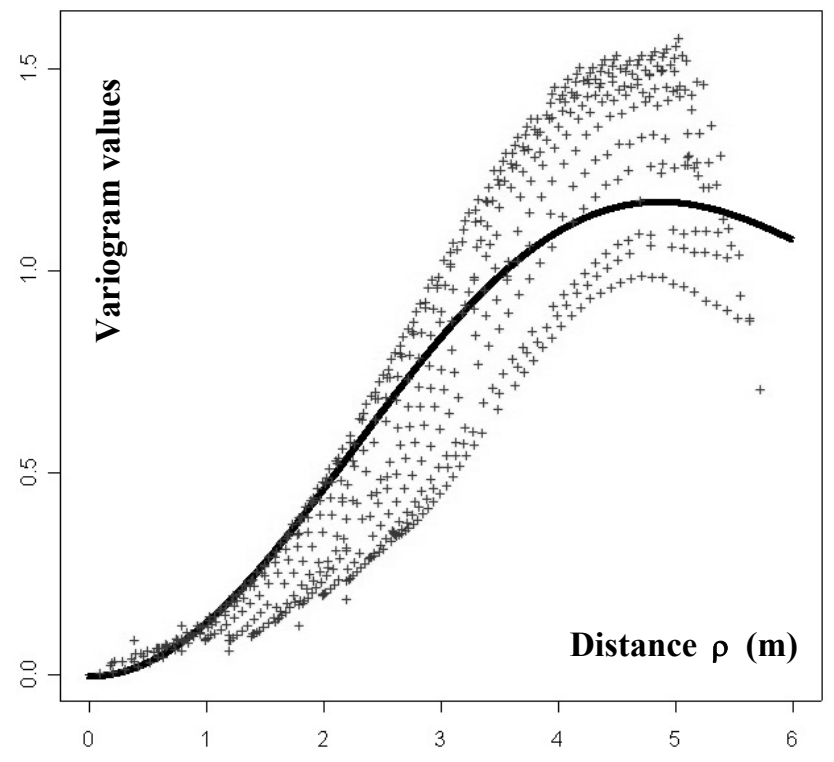

Fig. 3. Variogram of simulated and input data arrays $\Delta$ Tan for PR7-PR20, corresponding

$$
\text { to Bessel type correlation function } B(\rho)=\frac{2 J_{1}(a \rho)}{a \rho},\left(a \approx 3,25^{\star} 105\right)
$$

It is known [1] that variogram $\gamma(\rho)$ is related to the correlation function $B(\rho)$ with expression:

$$
\gamma(\rho)=B(0)-B(\rho)
$$

Variogram describes the dependence of the mean square difference of random field values (in general nonisotropic) at two points on the distance and direction between these points. This function for isotropic random field depends on the distance $\rho$ between points.

The spectral density $f(\lambda)=\Phi^{\prime}(\lambda)$ of homogeneous and isotropic random field $\xi(r, \varphi)$ on a plane can be determined [8] by its correlation function $B(\rho)$ as follows:

$$
f(\lambda)=\lambda \int_{0}^{\infty} x J_{0}(\lambda x) B(x) d x
$$

Since our noise data variogram corresponds to Bessel type correlation function (24), the spectral function for these data can be defined as follows:

$$
\Phi(\lambda)=\int_{0}^{\lambda} \mu \int_{0}^{\infty} x J_{0}(\mu x) B(x) d x d \mu
$$

Then the spectral function $\Phi(\lambda)$ can be calculated by the correlation function $B(\rho)$ in the expression:

$$
\Phi(\lambda)=\frac{2}{a} \int_{0}^{\lambda} \mu \int_{0}^{\infty} J_{0}(\mu x) J_{1}(a x) d x d \mu .
$$

The final stage was the imposing array of noise on the spline approximation of real data. As a result, we received more detailed implementation for the geomagnetic observation data in the selected area. The figure shows the maps that were built before numerical simulation and after completing the data set with double precision (Fig. 4).
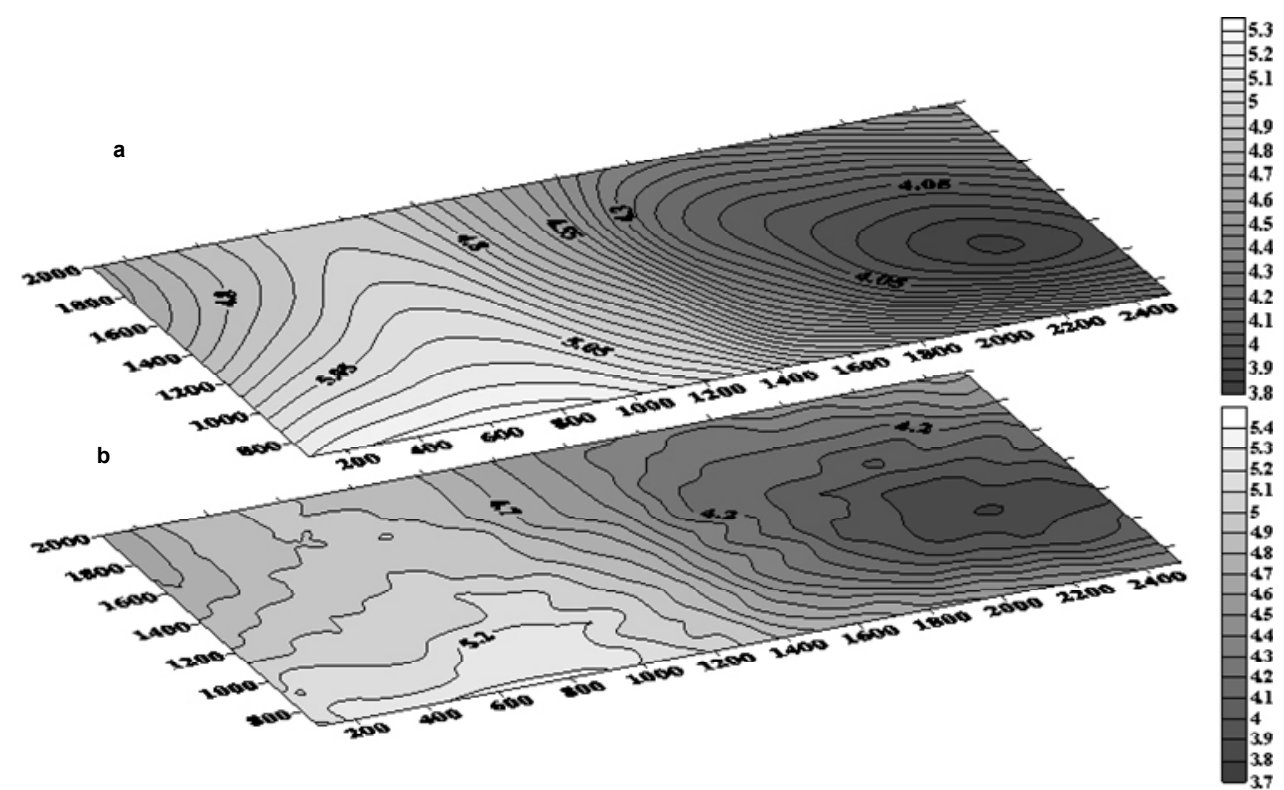

Fig. 4. Map of magnetic field $\Delta$ Tan (general) M: 1:10 000, (PR7, PR20) (a), map of simulated magnetic field $\Delta$ Tan M: $1: 10000$ (b) 
Conclusions. The statistical simulation method of random field implementations makes it possible to supplement with a given detail the measurement results of magnetic field full vector. It can also be used to identify abnormal areas. Such areas can be identified more accurately in the geomagnetic data, if to compare the actual deviation from the ideal random simulated geomagnetic field to the properties of homogeneity and isotropy.

СПИСОК ВИКОРИСТАНИХ ДЖЕРЕЛ:

1. Chiles J. P. Geostatistics: Modeling Spatial Uncertainty / J. P. Chiles, P. Delfiner. - New York, Toronto : John Wiley \& Sons, Inc., 1999. - 695 p.

2. Grikh Z. About Approximation and Statistical Simulation of Izotropic Fields / Z. Grikh, M. Yadrenko, O. Yadrenko // Random Operators and Stohastic Equations. - 1993. - Vol. 1, No. 1. - P. 37-45.

3. Yadrenko M. I. The Spectral Theory of Random Fields / M. I. Yadrenko. - New York, NY : Optimization Software Inc., Publications Division, 1983. $-259 \mathrm{p}$.

4. Вижва 3. О. Статистичне моделювання випадкових процесів та полів / 3. О. Вижва. - К.: Обрії, 2011. - 388 с.

5. Вижва 3. Статистичне моделювання випадкових полів на площині сплайновими апроксимаціями (на прикладі даних аеромагнітометрії) / 3 . Вижва, В. Демидов, А. Вижва // Вісник Київського уныверситету. Геологія. - 2010. - Вип. 51. - С. 31-36.

6. Ермаков С. М. Статистическое моделирование / С. М. Ермаков, Г. А. Михайлов. - М.: Наука,, 1982. - 296 с.

7. Михайлов Г. А. Приближенные модели случайных процессов и полей // Журн. вычисл. математики и мат. физики. - 1983. - Т. 23, № 3. C. $558-566$.

8. Пригарин С. М. Методы численного моделирования случайных процессов и полей / С. М. Пригарин ; гл ред Г. А. Михайлов. - Новосибирск: Изд-во ИВМ и МГ, 2005. - 259 с

\section{REFERENCES:}

1. Chiles J. P., Delfiner P. (1999). Geostatistics: Modeling Spatial Uncertainty. New York, Toronto: John Wiley \& Sons, Inc., 695 p.

2. Grikh Z., Yadrenko M., Yadrenko O. (1993). About Approximation and Statistical Simulation of Izotropic Fields. Random Operators and Stohastic Equations, 1(1), 37-45

3. Yadrenko M. I. (1983). The Spectral Theory of Random Fields. New York, NY: Optimization Software Inc., Publications Division, $259 \mathrm{p}$.

4. Vyzhva Z. O. (2011). The Statistical Simulation of Random Processes and Fields. Kyiv: Obrii, 388 p. [in Ukrainian].

5. Vyzhva Z., Demidov V., Vyzhva A. (2010) Statistical modelling of random fields on the plane using spline approximation (on example of airmagnetic data). Visnyk of Taras Shevchenko National University of Kyiv: Geology, 51, 31-36. [in Ukrainian].

6. Yermakov S. I., Mikhailov G. A. (1982). Statistical Simulation Course. Moskow: Nauka. [in Russian].
7. Mikhailov G. A. (1983). Approximate models of random processes and fields. Zh. Vychisliteln.mat. I mat. fiz., 23, 558-566. [In Russian].

4. Prigarin S. M. (2005). Numerical Modeling of Random Processes and Fields. G. A. Mikhailov (Ed. in Chief). Novosibirsk: Inst. of Comp. Math. and Math. Geoph. Publ., 259 p. [in Russian].

Надійшла до редколегії 01.12.16

Вижва 3., д-р фіз.-мат. наук, доц.,

E-mail: zoya_vyzhva@ukr.net,

Вижва А., магістр-геофізик,

E-mail: motomustanger@ukr.net,

Київський національний університет імені Тараса Шевченка,

ННІ "Інститут геології", вул. Васильківська, 90, м. Київ, 03022, Україна

\section{ПРО МЕТОДИ СТАТИСТИЧНОГО МОДЕЛЮВАННЯ ВИПАДКОВИХ ПОЛІВ НА ПЛОЩИНІ ДЛЯ ДАНИХ АЕРОМАГНІТОМЕТРІЇ}

Розроблено універсальні методи статистичного моделювання (методи Монте-Карло) геофізичних даних, які дають можливість вирішити проблеми генерування реалізацій випадкових полів на площині на сітці будь-якої регулярності та детальності. В геофізиці більшість результатів досліджень подається у иифровій формі, точність якої залежить від різних випадкових впливів (у тому числі, від похибки вимірювання апаратури). При цьому, виникає проблема кондиційності карт у випадку, коли дані неможливо отримати із заданою детальністю на деяких ділянках. Для вирішення проблем кондиційності карт, доповнення даними для досягнення необхідної точності та інших проблем подібного роду, в геофізичних задачах запропоновано застосовувати методи статистичного моделювання реалізацій випадкових процесів та багатовимірних випадкових функцій (випадкових полів). Використано теореми про оцінку середньоквадратичної та інших апроксимацій однорідних та ізотропних випадкових полів у двовимірному просторі частковими сумами рядів спеціального вигляду, за допомогою яких сформульовано алгоритми чисельного моделювання реалізацій таких випадкових полів методом рандомізації. Розроблено нову ефективну методику застосування до розв'язання геофізичних задач методів статистичного моделювання випадкових полів у двовимірному просторі (методу рандомізації, методу спектральних коефіцієнтів та ін.). На прикладі даних аеромагнітної зйомки в районі Овруцької западини впроваджено статистичне моделювання реалізацій випадкових полів на площині на основі спектрального розкладу у вирішення проблем кондиційності карт шляхом доповнення даних до необхідної детальності. При аналізі даних по профілях їх розділено на детерміновану та випадкову складові. Детерміновану складову даних пропонується наближати кубічними сплайнами, однорідну ізотропну випадкову складову - моделювати на основі спектрального розкладу випадкових полів. Модельний приклад - дані аеромагнітної зйомки в двовимірному варіанті (на площині). За наведеним алгоритмом було отримано реалізації випадкової складової на області дослідження із подвоєною детальністю по кожному профілю. При перевіриі їх на адекватність зроблено висновки, що відповідна гістограма випадкової складової має гауссівський розподіл. Побудована варіограма цих реалізацій має найкраще наближення теоретичною варіограмою, яка пов'язана із кореляційною функцією бесселевого типу. Завершальним етапом роботи було накладення масиву випадкової складової на сплайнову апроксимацію реальних даних. У результаті цього отримано більш детальну реалізацію для даних геомагнітних спостережень у виділеній області. Отже, метод статистичного моделювання реалізацій випадкових полів дає можливість доповнити із заданою детальністю даними результати вимірювань повного вектора напруженості магнітного поля.

Ключові слова: статистичне моделювання, метод рандомізації, сплайн-інтерполяція, кондиційність карт. 
Выжва 3., д-р физ.-мат. наук, доц.,

E-mail: zoya_vyzhva@ukr.net,

Выжва А., магистр-геофизик,

E-mail: motomustanger@ukr.net,

Киевский национальный университет имени Тараса Шевченко,

Уни "Институт геологии", ул. Васильковская, 90, г. Киев, 03022, Украина

\section{О МЕТОДАХ СТАТИСТИЧЕСКОГО МОДЕЛИРОВАНИЯ СЛУЧАЙНЫХ ПОЛЕЙ НА ПЛОСКОСТИ ДЛЯ ДАННЫХ АЭРОМАГНИТОМЕТРИИ}

Разработаны универсальные методы статистического моделирования (методы Монте-Карло) геофизичеких данных, которые дают возможность решить проблемы генерирования реализаций случайных полей на плоскости на сетке любой детальности и регулярности. В геофизике большинство результатов исследований подается в иифровой форме, точность которой зависит от разных случайных влияний (в том числе, от погрешности измерения аппаратуры). При этом возникает проблема кондиционности карт в случае, когда данные невозможно получить в некоторых участках. Для решения проблем кондиционности карт, дополнения данными для достижения необходимой точности и других проблем подобного рода, в геофизических задачах предлагается применять методы статистического моделирования реализаций случайных процессов и многомерных случайных функций (случайных полей). Использованы теоремы об оценке среднеквадратической и других аппроксимаций однородных и изотропных случайных полей в двухмерном пространстве частичными суммами рядов специального вида, при помощи которых сформулированы алгоритмы численного моделирования реализаций таких случайных полей методом рандомизации. Разработана новая эффективная методика применения при решении геофизических задач методов статистического моделирования случайных полей в двухмерном пространстве (метода рандомизации, метода спектральных коэффициентов и др.). На примере данных аэромагнитной съемки в районе Овручской впадинь разработана методика внедрения статистического моделирования случайных полей на плоскости на основании спектрального разложения в решение проблем кондиционности карт дополнением данных необходимой детальности. При анализе данных по профилям их разделяют на детерминированную и случайную составляющие. Детерминированную составляющую предлагается аппроксимировать кубическими сплайнами, однородную изотропную случайную составляющую - моделировать на основе спектрального разложения случайных полей. Модельный пример - данные аэромагнитной съемки в двумерном варианте (на плоскости). С помощью предложенного алгоритма были получены реализации случайной составляющей в области исследования с удвоенной детальностью по каждому профилю. При проверке их на адекватность сделаны выводы, что соответствующая гистограмма случайной составляющей имеет гауссовское распределение. Построенная вариограмма этих реализаций имеет наилучшее приближение теоретической вариограммой, которая связана с корреляционной функцией бесселевого типа. Заключительным этапом роботы было наложение массива случайной составляющей на сплайновую аппроксимацию реальных данных. В результате этого получена более детальная реализация для данных геомагнитных наблюдений в выделенной области. Таким образом, метод статистического моделирования реализаций случайных полей дает возможность дополнить с заданной детальностью данными результаты измерений полного вектора напряженности магнитного поля.

Ключевые слова: статистическое моделирование, метод рандомизации, сплайн-интерполяция, кондиционность карт. 